\title{
Identification of targets for antifungal drugs and vaccines: a literature review
}

\author{
Claúdio Junyo dos Santos ${ }^{1 *}$; Maria Vitória Lins da Silva² ; Pâmela Karolayne Rodrigues Barbosa ${ }^{3}$; \\ Marta Gabriely de Arruda Ribeiro ${ }^{4}$; Elianay Silva Lima ${ }^{5}$; Paulo César Barbosa de Brito Filho ${ }^{6}$; \\ Edilene Maria da Silva ${ }^{7}$; Bruna de Vasconcelos Dias ${ }^{8}$; Josslayne de Oliveira Albuquerque ${ }^{9}$; Elymax \\ Miquéias Lima Teodosio dos Santos ${ }^{10}$; Mayara Luciana Arruda da Silva ${ }^{11}$; Vitória Ramires dos \\ Santos Lira ${ }^{12}$; Ana Cláudia Barbosa de Morais ${ }^{13}$; Maria Clara Bezerra Gabu ${ }^{14}$; Tamires Eduarda \\ Ferreira Salvino $^{15}$; Fábio Abel de Carvalho ${ }^{16}$
}

1 Undergraduate in Pharmacy degree from the University Center of Vitória de Santo Antão - UNIVISA.

2 Bachelor's degree in Nursing from the University Center of Vitória de Santo Antão - UNIVISA.

3 Bachelor's degree in Nursing from the University Center of Vitória de Santo Antão - UNIVISA.

4 Bachelor's degree in Nursing from the University Center of Vitória de Santo Antão - UNIVISA.

5 Bachelor's degree in Nursing from the University Center of Vitória de Santo Antão - UNIVISA.

6 Undergraduate in Nutrition from the Federal University of Pernambuco - UFPE.

7 Bachelor's degree in Nursing from the University Center of Vitória de Santo Antão - UNIVISA.

8 Bachelor's degree in Nursing from the University Center of Vitória de Santo Antão - UNIVISA.

9 Bachelor's degree in Biomedicine from the University Center of Vitória de Santo Antão - UNIVISA.

10 Undergraduate in Pharmacy from the University Center of Vitória de Santo Antão - UNIVISA.

11 Bachelor's degree in Nursing from the University Center of Vitória de Santo Antão - UNIVISA.

12 Bachelor's degree in Nursing from the University Center of Vitória de Santo Antão - UNIVISA.

13 Bachelor's degree in Nursing from the University Center of Vitória de Santo Antão - UNIVISA.

14 Bachelor's degree in Physiotherapy from the University Center of Vitória de Santo Antão - UNIVISA.

15 Bachelor's degree in Nursing from the University Center of Vitória de Santo Antão - UNIVISA.

16 Undergraduate degree in Biological Sciences from the University Center of Vitória de Santo Antão - UNIVISA.

E-mail adresses: claudiojunyodossantos@gmail.com (Claúdio Junyo dos Santos), lynsvictoria@gmail.com (Maria Vitória Lins da Silva), karolaynepamela28@gmail.com (Pâmela Karolayne Rodrigues Barbosa), martagabriely06@gmail.com (Marta Gabriely de Arruda Ribeiro), elianaylima21@gmail.com (Elianay Silva Lima), thepaulobrito@gmail.com (Paulo César Barbosa de Brito Filho), edilene29.10@hotmail.com (Edilene Maria da Silva), brunavasconcelos692@gmail.com (Bruna de Vasconcelos Dias), josslayne@hotmail.com (Josslayne de Oliveira Albuquerque), elymaxmiqueias19@gmail.com (Elymax Miquéias Lima Teodosio dos Santos), Mayara_luciana@hotmail.com (Mayara Luciana Arruda da Silva), ramiresvitoria20@gmail.com (Vitória Ramires dos Santos Lira), aninha.morais.97112555@gmail.com(Ana Cláudia Barbosa de Morais), clara.gabu91@gmail.com (Maria Clara Bezerra Gabu), ferreirasalvino@outlook.com (Tamires Eduarda Ferreira Salvino), fbabel0@gmail.com (Fábio Abel de Carvalho).

${ }^{*}$ Corresponding author

\section{To cite this article:}

Santos, CJ.; Silva, MV.L.; Barbosa, P.K.R.; Ribeiro, M.G.A.; Lima, E.S.; Filho, P.C.B.B.; Silva, E.M.; Dias, B.V.; Albuquerque, J.O.; Santos, E.M.L.T.; Silva, M.L.A.; Lira, V.R.S.; Morais, A.C.B.; Gabu, M.C.B.; Salvino, T.E.F.; Carvalho, F.A. Identification of targets for antifungal drugs and vaccines: a literature review. International Journal of Sciences. Vol. 2, No. 3, 2021, pp. 23-26. ISSN $2763-5392$.

Received: 10 09, 2021; Accepted: 10 10, 2021; Published: 11 03, 2021

\begin{abstract}
Fungi, viruses and bacteria are microorganisms that can cause some pathologies in the body of humans. These pathologies can be treated or prevented, respectively, by antifungal drugs and vaccines. This study aimed to make a bibliographic review on the targets for antifungal drugs and vaccines, in view of the relevance of this theme, not only within the pharmaceutical area, but for health in general. Infectious processes caused by microorganisms, especially by fungal species, are very frequent in our country, because some regions have a tropical climate. Pathogenic microorganisms are distinguished from others of the same species by possessing and expressing genes that encode virulence factors. It is important to protect the patient through
\end{abstract}


2 Santos, CJ.; Silva, MV.L.; Barbosa, P.K.R.; Ribeiro, M.G.A.; Lima, E.S.; Filho, P.C.B.B.; Silva, E.M.; Dias, B.V.; Albuquerque, J.O.; Santos, E.M.L.T.; Silva, M.L.A.; Lira, V.R.S.; Morais, A.C.B.; Gabu, M.C.B.; Salvino, T.E.F.; Carvalho, F.A. Identification of targets for antifungal drugs and vaccines: a literature review...

immunization, which acts in the prevention of the pathology, and through antifungals that represent a kind of barrier against their targets.

Keywords: Pharmacy; Drugs; Fungus; Medication.

\section{Introduction}

According to the World Health Organization (WHO) about $25 \%$ of deaths worldwide are due to diseases caused by microorganisms. Within this total, about $45 \%$ occurs in underdeveloped countries, where the emergence of microorganisms resistant to various drugs has stood out as one of the main mortality factors (TINTINO et al., 2015).

Antifungal resistance continues to increase and evolve despite the emergence of new drugs, which makes it even more difficult to manage patients with invasive fungal infection (TAPIA, 2012).

Fungi, which are the main targets of antifungals, are dispersed beings in the environment, in vegetables, atmospheric air, soil and water, and although they are calculated in 250,000 species, less than 150 have been described as pathogens to humanity. But when faced with a pathogen species, they can cause several infectious conditions with localized or disseminated clinical forms (BRASIL, 2004).

Other forms of contracting pathologies by microorganisms are through bacteria and viruses that are, respectively, beings present in the human body and microorganisms that come into contact with it. Most, like fungi, do not cause us any problems; however, some may cause infectious diseases such as influenza, measles, hepatitis, among others, and to prevent this from occurring, there are specific vaccines for these diseases or for a group of them (HIPOLABOR, 2017).

One of the great advances in health prevention and promotion measures has been the breakdown of the links in the disease transmission chain, through the administration of immunobiological, including the vaccine (SANTOS et al., 2011).

Immunization is a proven action to control and eradicate infectious diseases and it is estimated that more than 30 doses of vaccine are administered globally every second and no other health intervention affects so many people, or is able to inhibit such a varied range of public health problems (FERREIRA et al., 2017).

This study aimed to make a bibliographic review on the targets for antifungal drugs and vaccines, in view of the relevance of this theme, not only within the pharmaceutical area, but for health in general, hoping that it will contribute to expand what is already known about the subject discussed.

\section{Methodology}

This is a study with data collection from secondary sources, through a bibliographic survey and based on the experience experienced by the authors at the time of an integrative review.

For the survey of articles in the literature, a search was conducted in the following databases: Latin American and Caribbean Literature on Health Sciences (LILACS), PubMed and Scientific Electronic Library Online (SciELO).

The methodology was given by the collection of articles, in a database scan, in addition to other complementary materials. The materials used and their respective sources are presented in Table 1 below.

\begin{tabular}{|c|c|}
\hline Database & Articles (by author and year) \\
\hline Google Scholar & $\begin{array}{l}\text { Andreotti (2006); Barros, Rosa } \\
\text { and Ribeiro (2017); Da Silva et } \\
\text { al. (2016); By Oliveira Pereira } \\
\text { et al. (2010); Mulu et al. } \\
\text { (2013); Plotkin and Plotkin } \\
\text { (2004); Plotkin and Plotkin } \\
\text { (2008); }\end{array}$ \\
\hline Capes Journals & $\begin{array}{l}\text { Caumo et al. (2010); Ferreira et } \\
\text { al. (2017); Juliano et al. (2008); } \\
\text { Santos et al. (2011); Tapia } \\
\text { (2012); Santos et al. (2012); }\end{array}$ \\
\hline Google & Brazil (2013); \\
\hline Scielo & $\begin{array}{l}\text { Aquino (2016); Azevedo } \\
\text { (2016); Nobre et al. (2002); } \\
\text { Brazil (2004); Vieira (2009); } \\
\text { Pinto, Pinto, I'm not Matta, } \\
\text { Matta. Da-Cruz (2011); Tintino } \\
\text { et al. (2015) }\end{array}$ \\
\hline
\end{tabular}

Source: Prepared by the authors.

\section{Results and Discussion}

Infectious processes caused by microorganisms, especially by fungal species, are very frequent in our country, because some regions, such as North, Midwest and Northeast, have a tropical climate. Therefore, an immense variety of tropical diseases with very diverse clinical conditions is produced, which has led to mycology having acquired an important role in the medical area (DE OLIVEIRA PEREIRA et al., 2010).

Fungi have great ecological and economic importance and are considered those of primary composers in all terrestrial ecosystems, form important associations with vascular plants (mycorrhized), constitute the vast majority of pathogens for plants, offer appropriate genetic systems for molecular biologists and are too important for biotechnology. 
They can produce infection in the skin, hair, nails, mucous membranes, subcutaneous tissue, organs and systems, occupying a prominent place within the panorama of tropical diseases (DE OLIVEIRA PEREIRA et al., 2010).

By Oliveira Pereira et al. (2010), it also says that soil and atmospheric air constitute the great habitat of fungi, being considered the main sources of infections or reservoirs thereof. In recent years, several diseases from microorganisms in the environment have been detected with increasing importance. Environmental fungi are generally not pathogenic, but act as opportunistic pathogens. It is important to remember that, in these situations, these microorganisms can actually play the role of primary agents in fungal infections processes, often with fatal consequences for man.

Studies on the occurrence of environmental fungi, generally considered opportunistic and contaminants, are important for the prevention and treatment of pathologies affecting man, animals and plants. It may also allow advances in the diagnosis and development of new approach methods in these pathologies (DE OLIVEIRA PEREIRA et al., 2010).

\section{SANTOS et al. (2012) reports that:}

"The addition of pathogenic microorganisms to host tissues is considered indispensable for the beginning of colonization and progression of the infectious process. It implies that the pathogen recognizes either binding proteins on the surface of the host cell or proteins that are constituents of the basement membrane."

According to Andreotti (2006), the success of colonization of host tissues by pathogenic fungi is a complex process, which most often involves adhesin proteins produced by the pathogen itself and a cell receptor. Microorganisms can interact with three types of host components, such as: cell-secreted products, host cell surfaces, or extracellular matrix proteins (MEC), such as type I and IV collagens, fibronectin, fibrinogen, and laminiin.

Antifungals play an important role in obtaining effective therapy for patients affected by infections. The main groups of systemic antifungals commonly used for the treatment of pathologies caused by fungi are imidazole's (ketoconazole), triazoles (fluconazole and itraconazole) and allylamine (terbinafine) (DA SILVA et al., 2016).

Antifungal resistance may originate: a) primary, when the strain is naturally resistant before being exposed to the drug, or b) secondary or acquired, when the resistance is originated by acquisition or modification of genetic material, allowing such microorganisms to survive and reproduce, even in the presence of the drug (AZEVEDO, 2016).

Pathogenicity is defined as the ability of a microorganism to cause disease. Pathogenic microorganisms are distinguished from others of the same species by possessing and expressing genes that encode virulence factors, that is, factors that cause colonization and occurrence of several events that perpetuate host physiology, causing the appearance of abnormal signs and symptoms, which will finally define the state of disease. Among the most important virulence factors are adhesins, which allow microorganisms to colonize tissues; toxins, invasines, iron uptake systems, and factors that allude host defenses. In addition, the acquisition of genes that allow resistance to antimicrobial drugs has become an additional element in the virulence arsenal of bacteria (VIEIRA, 2009).

Another form of acquisition of genes involved with virulence is through processes of transfer of genetic material between bacteria. In this case, nonpathogenic bacteria acquire exogenous DNA and can evolve into pathogens. Three basic forms of genetic material transfer between bacteria are known: I. through a phenomenon called conjugation, where contact with other living bacteria allows the transfer of virulence genes present in an extrachromosomal DNA molecule called plasmid; II. capturing free DNA in the environment in a process called transformation and, finally, III. by a phenomenon called transduction or lysogenic conversion, where viruses infecting bacteria (bacteriophages) transfer virulence genes to them (VIEIRA, 2009).

Despite the great diversity of chemical structures and different mechanisms of action of antimicrobials, the treatment of infections caused by resistant microorganisms has been increasingly difficult (MULU et al., 2013).

The increased incidence of antibiotic-resistant microbial infections, acquired both in the community and in hospitals, has drawn the attention of the health community. On the other hand, in recent decades, there has been a decrease in the number of antibiotics approved by the FDA and only two drugs with new mechanisms of action have reached the market in the last 40 years, linezolid and daptomycin (CAUMO et al., 2010).

Plotkin and Plotkin (2008) say that no other product, not even antibiotics, has had as much effect in reducing mortality and has influenced both the growth of the world population and the development of vaccines.

Juliano et al. (2008) says that the Brazilian Ministry of Health, in 1973, created the National Immunization Program (PNI). The technological model adopted by it in the control of diseases that can be taken care of combines a number of elements: routine vaccination, national vaccination days, periodic campaigns and epidemiological surveillance. SANTOS et al. (2011), complements the text above with the following saying:

"The National Immunization Program (PNI) was established in Brazil in 1973 with the purpose of ensuring immunization for the entire Brazilian population, through the municipalities and health services of the basic network. Initially, it met the emergency needs of the tuberculosis control program and the eradication of smallpox. Law No. 6,259/75 institutionalized the program and defined the competencies and responsibilities related to its implementation."

Shortly after the institutionalization of this Program, improvements in health indicators such as infant mortality and mortality of children under 5 years were found, with 
4 Santos, CJ.; Silva, MV.L.; Barbosa, P.K.R.; Ribeiro, M.G.A.; Lima, E.S.; Filho, P.C.B.B.; Silva, E.M.; Dias, B.V.; Albuquerque, J.O.; Santos, E.M.L.T.; Silva, M.L.A.; Lira, V.R.S.; Morais, A.C.B.; Gabu, M.C.B.; Salvino, T.E.F.; Carvalho, F.A. Identification of targets for antifungal drugs and vaccines: a literature review...

emphasis on the decrease in incidence rates of preventable diseases in the scope of vaccines offered by the PNI (AQUINO, 2016).

There has been progress observed from the beginning of immunization practice to the new vaccine strategies and this has an impact on reducing the incidence of diseases. It is expected to control or even eradicate diseases in the near future (PINTO; MATTA; DA-CRUZ, 2011).

\section{Conclusions}

It has become noticeable with this work that infectious processes are very constant in our country, whether by fungi, bacteria, or any other microorganism. Therefore, it is important to protect the patient through immunization, which acts in the prevention of the pathology, and through antifungals' that represent a kind of barrier against their targets.

Because it is a literature review, it was not up to the text to bring concrete data or case studies. However, among the literature consulted, case studies only proved the efficiency of everything that was defended here.

Finally, it is expected that this work will contribute significantly to obtaining the knowledge of the scientific community in order to collaborate with the studies already carried out on the same theme and further expand the line of research.

\section{References}

[1] ANDREOTTI, Patrícia Ferrari. Interação de Paracoccidiodes brasiliensis com células epiteliais. Caracterização de prováveis fatores de virulência. 2006.

[2] AQUINO, Lais Martins de. Programa Nacional de Imunizações: a evolução do calendário de vacinação por meio da implantação de novas vacinas nos últimos 10 anos. 2016.

[3] AZEVEDO, G.S.G. Perfil antifúngico (in vitro) e toxicológico (in silico) de moléculas de origem sintética e extratos de origem marinha frente a Candida spp. da American Type Culture Collection (ATCC) e isoladas de microbiota oral. 2016. $112 \mathrm{f}$. Dissertação (Mestrado em Ciências e Biotecnologia) Universidade Federal Fluminense, Rio de Janeiro, 2016.

[4] BRASIL. Agência Nacional de Vigilância Sanitária. Detecção e Identificação dos Fungos de Importância Médica (MÓDULO VII). Disponível em< http://www.anvisa.gov.br/servicosaude/microbiologia/mod_7_ 2004.pdf>. Acesso em: 25/09/2019.

[5] CAUMO, Karin Silva et al. Resistência bacteriana no meio ambiente e implicações na clínica hospitalar. Revista Liberato: revista de divulgação de educação, ciência e tecnologia. Novo Hamburgo, RS. Vol. 11, n. 16 (jul./dez. 2010), p. 89-188, 2010.

[6] DA SILVA, Gabriela de Souza et al. Efeito mutagênico ex vivo do antifúngico fluconazol em leucócitos humanos. Anais do Salão Internacional de Ensino, Pesquisa e Extensão, v. 7, n. 4, 2016.

[7] DA SILVA SANTOS, Rodrigo et al. Interações Moleculares Mediadas por Proteínas de Adesão Celular Levam À
Sobrevivência e Sucesso na Infecção Causada por Fungos Patogênicos em Humanos. Saúde e Pesquisa, v. 5, n. 1, 2012.

[8] DE OLIVEIRA PEREIRA, Fillipe et al. Microbiota fúngica do solo e ar atmosférico na região da Borborema, estado da Paraíba, Brasil. RBAC, v. 42, n. 2, p. 123-126, 2010.

[9] FERREIRA, Ariana Vitalina et al. Acesso à sala de vacinas nos serviços de atenção primária à saúde. Revista Eletrônica de Enfermagem, v. 19, 2017. Acesso em: 24/09/2019; 19: a 31. Disponível em: http://dx.doi.org/10.5216/ree.v19.42468.

[10] JULIANO, Yára et al. Segunda etapa da Campanha Nacional de Multivacinação do município de São Paulo, 2005: perfil de cobertura de diferentes Unidades Básicas de Saúde. Rev Paul Pediatr, v. 26, n. 1, p. 14-9, 2008.

[11] MULU, Andargachew et al. Detecção frequente de espécies de Candida resistentes a 'azole' entre pacientes com AIDS de apresentação tardia no noroeste da Etiópia. Doenças infecciosas de BMC, v. 13, n. 1, pág. 1-10, 2013.

[12] FONSECA PINTO, EDUARDO; MATTA, NUBIA ESTELA; Vacinas DA-CRUZ, ALDA: Avanços e desafios para o controle de doenças evitáveis. Acta Biológica Colombiana, v. 16, n. 3, pág. 197-212, 2011.

[13] PLOTKIN, Susan L.; PLOTKIN, Stanley A. Una breve historia de vacinação. Vaccines, v. 5, p. 1-16, 2004.

[14] SANTOS, Paula Raquel dos et al. Enfermagem e atenção à saúde do trabalhador: a experiência da ação de imunização na Fiocruz/Manguinhos. Ciência \& Saúde Coletiva, v. 16, p. 553$565,2011$.

[15] TAPIA, Cecilia. Antifúngicos y resistencia. Revista chilena de infectología, v. 29, n. 3, p. 357-357, 2012.

[16] TINTINO, Saulo R. et al. Avaliação da atividade antibacteriana y moduladora de aminoglicosídeos do óleo essencial de Cymbopogon citratus (DC.) Stapf. Acta Biológica Colombiana.

[17] VIEIRA, Mônica Aparecida Midolli. Ilhas de patogenicidade. O mundo da saúde, v. 33, n. 4, p. 406-414, 2009. 